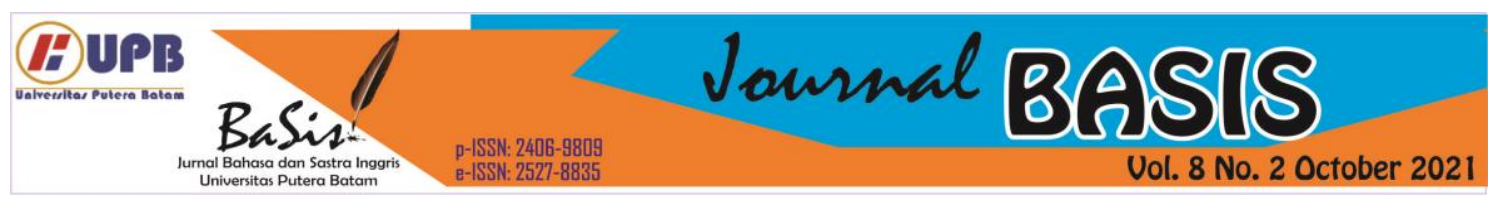

\title{
THE STEREOTYPE TOWARDS WOMAN REFLECTED IN THE NOVEL "ON THE COME UP" BY ANGIE THOMAS
}

\author{
Mutia Rafael \\ Universitas Putera Batam (UPB), Batam, Indonesia \\ mutiiaaw@gmail.com \\ Tomi Arianto \\ Universitas Putera Batam (UPB), Batam, Indonesia \\ tomi.arianto@puterabatam.ac.id
}

\begin{abstract}
Stereotypes created by society toward women still can be found around. Women could not be leaders, could not have a decent job, did not have to have high education, and their position only to please their family. In this research the researcher is discussing about stereotypes that happened towards women. By using Barbara Walter's theory, where it is portrayed how men find women should be under their position whether in work position or in general, this study is examined. The method used in this research is qualitative method, where the data taken from sentences or conversations from the novel On the Come Up by Angie Thomas. The results of this study indicate the main character is not following the stereotypes that society has created. It can be concluded that she is not the ideal type based on societal stereotypes.
\end{abstract}

Keywords: Stereotypes, Feminism, Woman, On the Come Up.

\section{INTRODUCTION}

In modern era, many women started to express their passions whether it suits to their gender or not. Nowadays, women are starting to ignore about stereotypes. They keep doing things to get out of their proper place as women. For example, women follow their passion. Although it is possible, some might still have to struggle to achieve their passion because of society's expectation towards women. Thus, women still can't get to choose freely and therefore still have to fight for their place in the society because of the stereotypes of how women should behave.

Along with the times, feminism and the stereotypes that are the root of this problem also develop through times. There are still of the stereotypes stay as before, some that are removed, but there are also new stereotypes evolve depend to the conditions and times. This makes women unable to move freely because of social judgments. One of the basic stereotypes that shockingly can still be found to this day is how women ideally please their families or husbands. When women choose to pursue their careers, many disagree because it will not benefit their superiors. This phenomenon continues to be found to occur, not least in the world of rappers, where men are more dominant. Some argue that popular music over the past three decades is also part of a larger cultural resistance to feminism, an attempt to block progress toward gender equality and resuscitate male domination (Weitzer \& Kubrin, 2009).

This justice and equality is also demanded by women who really want change at that time. Most women at that time were trapped in a thought that 
women are a weak gender that is not important and is not needed as a part of the agent of change. As women they are expected and better focus on the household if they want to succeed in the eyes of society. This is an old-fashioned assumption that they are trying to break in order to gain equality in engaging in important parts. They demand equality in many fields, such as playing a role in an important position and being able to become one of the agents of change.

In this novel, the struggle comes from Brianna. Brianna as a teenager has a lot of struggle in achieving her dream to become a rapper. Besides lack of support from her family, people also underestimate her because she might not as great as her late father and she might only get famous because of her father's name. In the rapper industry, female rapper is not as common as male rapper. Thus being said, Brianna still won't give up her dream to become a rapper.

In Hip-Hop world, image of women in popular music like rapper is not very likely. The gender stereotypes in popular music portrayed women as inferior. This happens because of women's persona and society roles. Moreover, it doesn't suit women's images because the stereotypes of women need to be graceful as they can be a great image for their children and as for rappers, they tend to speak their concern through the lyrics and sometimes the language is not pleasant to hear. As stated in (Weitzer \& Kubrin, 2009) women were present depicted them in a "conventional" manner (passive, dependent on men, accenting physical appearance).

In the novel, the writer wants to examine the background story related to feminism. The story portrayed how women are regulated and set standards to match the expectations of society. As a result of the expectation of achieving these standards, these women become free and lose their identity. They then competed to be as perfect as possible in the eyes of the community. In connection with this explanation, the novel "On The Come Up" will be very interesting to study, because the novel tells about the background of a woman who struggles in order to achieve her goals, namely working as a rapper.

\section{LITERATURE REVIEW}

Feminism is the belief that women and men basically have equal values, in which this movement by women rejects everything that marginalizes, subordinates, or demeans the dominant (Desmawati, 2018). In other word, Feminism isn't only discussing about how women should get the same respect, it also talks about how women should have an equal position on political, economic, and social right just like those of men.

There's a lot of theory that discussing about feminism. Feminism considered as a belief that operates within a group, which means the desire to increase women's autonomy, in other word feminism means the movement or efforts of a group of people who oriented towards changing women's position. Feminism and the gap on the social reality have a long history and it been happening since years ago. This creates variety perception and concept based on what happen which became the theoretical basis for the thought of Feminist Legal theory.

Stereotypes that develop and are followed by society are generally based on a kind of belief that must be owned or adhered to by certain people or groups. As stated by Barbara Welters and redefined by Arianto \& Ambalegin (2018) Stereotypes are a perception of a group that can be a belief of a person or group of people who grew up in the same community as the way they should behave and act. Women are actually pious, holy, obedient and good in 
household. No matter the form of achievement or excellence of a woman, without these four things all are meaningless. In her theory, Welter described back then in her era, women did not have the right to choose and had the opportunity to pursue their dreams because stereotypes always told women that they didn't have to be successful because of their place in the kitchen. For example, women are responsible for the satisfaction of their husbands, in other words they need to make sure that they only have to pay attention to housework and follow all the rules that men make. As time passes, where people's thoughts and views also developed, the same main problem in feminism is still found today. With the book entitled On the Come Up was written by Angie Thomas in February 2019, portrayed how society in the modern era reacts to a change or development in women with the same response as before. The book itself won an award of number one New York Times Bestseller. Her love for Hip Hop industry made her wrote this novel because according to her hip hop can help people to be more aware of societal issues. She also stated that rappers can pull out words of criticism since freedom of speech is not always free. One of the societal issues is how people see women in Hip Hop industry as an obstacle of men's successes.

Issues about feminism have been discussed before. Studies show these two phenomenon have been around since women keep doing rebellion seeking their passion and come out from their proper place. The first study was completely done by (Alya et al., 2015). The paper examines the interpellation of misogyny by female characters in the novel entitled EILEEN. Their paper has examined two methods: form of misogynistic women and the way misogyny can get interpolated. The method that was used in this paper is descriptive qualitative. The result of this paper is the misogyny happens not only because of men but women also support this idea.

The second study was taken from a novel entitled "Pride and Prejudice". The aim of this research is to find out about the types of sexism language that is used in this novel (Sri Minda Murni, 2017). The method that was used during this research is qualitative method. The result of this research is there are three types of sexist language that is used in this novel. Those are Metaphors, Marked and Unmarked, and Generalization.

The third study was taken from a novel entitled "The Book Thief". The research is focused in analyzing the indicator of main character's resistance towards Nazi (Windratama, 2019). This research was using qualitative method. The aim of her research is to find out about the resistance indicator of the main character. The result shows there are four indicators. Those are the difference of ideology, making alliance with Nazi enemy, humiliation, and the feeling of empathy towards other race and ethic.

The last significant previous research was discussed by Arianto, T \& Simanjuntak D (2021) that raised the phenomenon woman stereotype with paradoxically. They distort a stereotype of society that has seen the character of The Spirit of Mak Ungkai as a woman who guards nature. With a combination of ecofeminism, they reveal something unusual. The stereotype of witches, scary ghosts, turns out to have a hidden meaning as a human protector who is in charge of balancing humans and nature.

As for the previous study, until the writer writes this, this novel hasn't been used as the source before. Even though this novel has not been used before, the issues about feminism are still appeared in this day. 


\section{RESEARCH METHOD}

In this research, the researcher will be using Qualitative Method. According to Bogdan and Taylor, qualitative methods are research procedures that produce data in the form of descriptive written or verbal words from people and observable behavior (Taylor et al., 2015). The researcher chooses the qualitative because the data is from the novel contains relative in social life. The data itself do not contain any numerical. In this research there will be two stages involved. The first stage is the data collection stage. Data collection will be a set of ways or techniques which are an extension of the human senses because the aim is to collect empirical facts related to the research problem. The second, the data will be processed on the analysis phase.

\section{RESULT AND DISCUSSION}

After reading the novel, the researcher found some data related to the topic. All the data that the researcher has collected refer to feminism faced by one of the characters in achieving her dream. In the novel, it was stated that being rapper is not something women should do. Expectations that are embedded in the community in her environment where the majority of rappers are men have taken root in and become a reference as how it is impossible to be a successful field for her.

Misogyny in Hip Hop Industry.

"We go inside. As usual it's mostly guys in here, but I see a few girls too (which is reflective of the small ratio of women to men in hip-hop, which is total misogynistic fuckery, but anyway...There are kids who look like they came straight from Garden Heights High, (Thomas, 2019, p. 20)
From the data above it can be seen that Brianna as the main character can tell that rappers world is mostly dominated by men. In the story, there is ring battle to show their ability and if someone can make it out alive it may be one of ways to make them a famous rapper in the neighborhood and in hope that they will sign a contract with any label. When she first came to the ring battle she noticed there are only few women which she was seen it as a misogyny phenomenon as the definition itself is hatred towards women. She used form of "misogyny" to describe the situation as the way men have privilege in choosing everything, such as job field that was dominated by men. This phenomenon happens as the expectation of women as a pure human being and the misogynist view as only men who have all potential in everything.

Women considered as minority.

"Hold up, you made that for this li'l girl?" some guy on the couch asks. "What she gon' do, spit some nursery rhymes?” (Thomas, 2019, p. 74)

From the data above the sequence happens after Brianna won in the battle rings. Her aunt decided to put her under the label of her best friend named Doc. In the room, there is a man mocking her because she is a girl which seems to be wrong already. They think that women do not have the ability to become a rapper as the way he said "nursery rhymes" as a reference for traditional song for children. He doesn't see Brianna as a young rapper, rather see as a girl that doesn't have any potential at all even though she won the battle.

Showing Feminine Side is Forbidden.

"This is that stale and predictable shit Aunt Pooh warned me about when I first told her I wanted to be a rapper. She said I'd have to do 
double the work to get half the respect. On top of that, I gotta be just as cutthroat, and I better not show weakness. Basically, I gotta be one of the guys and then some in order to survive." (Thomas, 2019, p. 74)

In the data above, it can be seen that from the very beginning becoming a rapper is hard for her because she is a woman. She stated that her aunt reminds her to not show any weakness as to build a strong image that can intimidate the opposite gender. The slang of "cutthroat" meaning that she has to be ruthless to be in the position she wanted. In other word in order to survive she needs to hide her feminine side and be one of the guys. The stereotypes in Hip Hop industry showing that if women want to be a rapper, they need to work twice harder.

Women Are Expected to Have a Lower Position.

I shake his hand. "It's fine. No more hard feelings."

"No more?"

"Hey, you had to know there were some. That's why you apologized, right?"

"Accurate," he says. "It wasn't personal. I wasn't prepared for you to come back as hard as you did though."

"What? Surprised that a girl beat you?" (Thomas, 2019, p. 147)

In this data it shows the relationship between Miles and Brianna. Miles is a rapper whose age is the same as Bri. Since he is a boy and his father is also a rapper, it makes him easier to get into the battle rings. As expected on how they make up their relationship and Bri stated that a girl can beat him as for many times he always wins the battle. As the Hip Hop industry is always dominated by male. The stereotype as women should be in second position is showing in this data.

Women are as successful as men.

"Hell yeah." Miles sits forward a little. "But let's be real: Lil' Kim is the ultimate queen bee." "Um, of course." Jay's a fool for Lil' Kim. I grew up on her.

Hearing Kim told me that not only can girls rap, but they can hold their own with the boys. (Thomas, 2019, p.147)

The data shows a conversation between Bri and Miles. Lil' Kim refers to one of the female artists. While having a conversation, Miles praises Lil' Kim because of her talent. Bri agrees with his opinion, she also said that girls can rap and use a phrase "can hold their own" meaning they can be as successful as men. The stereotypes of saying women better to not be a rapper because of their lack of intelligence is too generalizing, in fact there is a female rapper that has succeed in this field. Even though rappers' world is dominated with mean that doesn't mean women can't have the opportunity because women also have potential in them.

A successful woman is a shocking news.

"Look, I'm not trying to come at you," Hype claims. "I love the song. I can't lie though, knowing that a sixteen-year-old girl is talking about being strapped and stuff like that, it caught me off guard."

Not that a sixteen-year-old rapped about it. But that a sixteen-yearold girl rapped about it. "No." (Thomas, 2019, p. 46)

In this data, it shows the conversation between Hype and Brianna. They are having a conversation after Bri releases a new song that is mainly not a pleasure word to hear. 
When Hype mentions "a sixteen-yearold girl", it really makes Brianna a little furious because he says it as it is a wrongdoing. Though the stereotype built by society as discussed in Welters theory are broken because of Bri's success in her career as a rapper, it is still taken as something that not sit right that when it is done by women. Then she mentions again about her late father, if he rapped about it will it be shocking news to him or not. As expected he said no because of the stereotypes of women should maintain their act and purity.

\section{CONCLUSION}

In conclusion, women are expected to follow all the stereotypes the society has created. Women are pressured to follow some set to fulfill the expectation. Looking through Brianna's life how she struggles to achieve her dream as a rapper can show the reader of how women need to work twice harder as to build the strong image. They had to inure many forms of injustices, societal expectation and did not get many rights that they should have had. For instance, how they only expect women to have lower class and do not have the expectation if women also can be dominance in certain field. From the result and data, it shows that Hip Hop is dominated by men. As the conclusion, if there is a woman that can win in the battle ring they are surprised. Women are also only viewed to have lack of ability.

\section{REFERENCES}

Alya, L., Ningsih, S., \& Wahyuni, D. (2015). The interpellation of misogyny by female characters in novel EILEEN by otessa moshfegh (2015). 9(3).

Arianto, T., \& Ambalegin, A. (2018).
Indoctrination Against Women in "The Lowland" by Jhumpa Lahiri. OKARA: Jurnal Bahasa Dan Sastra, $\quad 12(2), \quad 153$. https://doi.org/10.19105/ojbs.v12i2. 1935

Arianto, T., \& Simanjuntak, D. (2021). Paradoxical Representation of Female Naration in the Spirit of Mak Ungkai Story. Jurnal Basis, [S.1.], v. 6, n. 2, p. 173-184, oct. 2019. ISSN 2527-8835. Available at:

http://ejournal.upbatam.ac.id/index. php/basis/article/view/1413

Desmawati, E. (2018). Analysis of Feminism in the Novel of Little Women By Louisa May Alcott. Journal of Language and Literature, 6(2), 91-96. https://doi.org/10.35760/j1l.2018.v6 i2. 2487

Sri Minda Murni, W. B. M. A. (2017). The sexism in jane austen's pride and prejudice. Linguistica, 6(2). https://doi.org/10.24114/ling.v6i2.7 586

Taylor, S., Bogdan, R., \& DeVault, M. (2015). Introduction to Qualitative Research Methods (4th Editio, Vol. 3, Issue 2). John Wiley \& Sons, Inc.

http://repositorio.unan.edu.ni/2986/ 1/5624.pdf

Thomas, A. (2019). On the come up (1st Editio). Balzer + Bray.

Weitzer, R., \& Kubrin, C. E. (2009). Misogyny in Rap Music. Men and Masculinities, 12(1), 3-29. https://doi.org/10.1177/1097184x0 8327696

Windratama, F. (2019). Woman resistance against nazi regime reflected in markus zusak's The book thief. 